\title{
Epidermal growth factor receptor in the vesical urothelium of paraplegic and tetraplegic patients: an immunohistochemical study
}

\author{
D van Velzen ${ }^{1}$, KR Krishnan ${ }^{2}$, KF Parsons ${ }^{2}$, BM Soni ${ }^{2}$, MH Fraser ${ }^{2}$ and S Vaidyanathan ${ }^{2}$ \\ ${ }^{I}$ Department of Fetal and Infant Pathology, University of Liverpool, Liverpool; ${ }^{2}$ Regional Spinal Injuries Centre, \\ Southport PR8 6PN, UK
}

Spinal cord injury (SCI) patients are at high risk of developing cystitis, and vesical neoplasia. As abnormal growth regulation of urothelium may be a predisposing factor for cystitis and vesical neoplasia, we studied alterations if any, in the expression and localization of epidermal growth factor receptor (EGRF) in the vesical urothelium by an immuno-histochemical technique, using monoclonal mouse anti-human epidermal growth factor receptor antibody (DAKO-EGFR1) in cold-cup biopsies taken from the trigone of the urinary bladder in 18 adult SCI patients who had a neuropathic bladder. Abnormal localisation of EGFR-p, i.e. cytoplasmic, was noted in 13 patients. A linear localization of EGFR-p along the cell membrane of the urothelium, considered as an essential requirement for effective function, was observed in only three cases. Combined cytoplasmic and cell membrane location of EGFR-p was seen in two patients. The three patients with cell membrane location of EGFR-p showed a strong expression of EGFR-p $\left(2^{+}, 2-3^{+}\right.$, and $4^{+}$, respectively); the intensity of EGFR-p expression in cases of cytoplasmic immunostaining varied considerably. Histopathology revealed denuding cystitis in one; follicular cystitis in four; active inflammatory infiltrate in three; lymphocytic infiltrate in three; squamous metaplasia in six; and intestinal metaplasia in three biopsy specimens.

The three specimens showing cell membrane location of EGFR-p were from patients who did not have an indwelling urethral catheter (a paraplegic man practising intermittent selfcatheterisation, a tetraplegic patient on penile condom drainage, and a tetraplegic woman with reflex voiding), and histopathology revealed very little inflammatory infiltrate. In contrast, the biopsies from all the nine patients, who were on indwelling urethral catheter drainage and in whom the bladder biopsy revealed varying degree of cystitis, showed only cytoplasmic location of EGFR-p. Similarly, the biopsies from patients with bladder stone $(n=6)$ showed only cytoplasmic localisation of EGFR-p. In conclusion, abnormalities in vesical urothelial expression in EGFR in SCI patients may play a role in the pathogenesis of cystitis, vesical urothelial metaplasia, dysplasia and neoplasia.

Keywords: epidermal growth factor receptor (EGFR); spinal cord injury; neuropathic bladder; vesical neoplasia; vesical dysplasia and metaphasia; vesical urothelial proliferation

\section{Introduction}

Growth factors are relatively small proteins that interact with cells to regulate cell biology. Cellular processes responsive to trophic factors are myriad but include such fundamental issues as proliferation, differentiation, adhesion, motility, peri-cellular proteolysis, and extracellular matrix production. ${ }^{1}$ Ultimately, growth factors influence cell biology by regulating gene expression. For a given growth factor, changes in concentration, surface receptor number, type, occupancy, and second messenger signal transduction are important determinants of both the nature and

Correspondence: Mr S Vaidyanathan, MS, MCh, Ph.D., Registrar in Spinal Injuries, Regional Spinal Injuries Centre, District General Hospital, Town Lane, Kew, Southport, Merseyside PR8 6PN, UK magnitude of downstream events. The specificity of growth factor action is mediated by the interaction of ligand with cognate receptors resulting in the triggering of a defined biochemical pathway. Ultimately, a mitogenic or differentiation signal is delivered to the nucleus, completing the biological action of the growth factor. As growth factors play important roles in both normal and abnormal biology, defining the role of these cytokines in specific disease processes will help us towards greater understanding of the pathophysiological process as well as provide us with new opportunities for diagnostic and therapeutic strategies for the treatment of the disease, e.g. urothelial proliferation disorders in spinal cord injury patients.

The Epidermal Growth Factor (EGF) belongs to a 
rapidly expanding family of peptide mitogens. ${ }^{2}$ The kidney is postulated to be the source of urinary EGF, which is excreted in urine in high concentrations in a biologically active form. ${ }^{3}$ Detection of EGF-Receptor protein is restricted to the basal and intermediate cell layers of normal urothelium of the bladder. ${ }^{3}$ Cell surface staining, indicative of integration of the antigen bearing proteins in functional receptors to the ligand-binding portion of human EGFR on normal bladder urothelium did not reveal cell membrane localisation of receptor protein in superficial urothelial cells. In constrast, $10 \%$ to $50 \%$ of cells in the intermediate layers showed positivity distributed in small aggregates of positive cells. No information was presented with respect to cytoplasmic/cell membrane localisation. The basal layers of the bladder urothelium showed consistent strong staining of cells, at an intensity of stain similar to that of simultaneously stained positive tissue controls (human transitional cell carcinoma cells $647 \mathrm{~V}$ growing as subcutaneous abdominal wall tumours in nude female Fischer rats). Again cytoplasmic/membrane localisation in these studies was difficult to evaluate and no conclusion is presented.

Epidermal Growth Factor is excreted in the urine in very high concentration in a biologically active form and this would suggest that in addition to a functional role, even functionally activating basement membrane transgressing, epithelium anchoring cell processes, there may be functional EGF-Receptors in higher layers. Thus, depending on the permeability of the superficial lining, there may be an opportunity to react with cells of the bladder epithelium on a continual basis. In experimental models this is substantiated as a 45 to 60 minute exposure of the moderately distended rat bladder to intravesical EGF, stimulated doserelated intramural induction of ornithine decarboxylase activity and DNA synthesis in the basal urothelial cell layer. ${ }^{4}$ However, in order to respond to EGF, cells must have functional, cell surface located receptors which allow for specific binding.

Vesical urothelial proliferation has been demonstrated in some spinal cord injury patients. ${ }^{5}$ A strategy aimed at optimizing urothelial proliferation in order to normalize differentiation-dependent surface characteristics possibly influencing the propensity for pathological bacterial colonisation, may consider the use of EGF or EGF-like growth factor by intravesical instillation. Success for this strategy would require the continued expression of sufficient amounts of functional EGF receptors on the cell surface of the bladder urothelium, although expression on superficial cells, in the light of experimental and physiological data is probably not required. It is possible that the

Table 1 Resume of clinical details of 18 patients in whom the urinary bladder trigone biopsies were studied by immunohistochemical staining for epidermal growth factor receptor in the urothelium

\begin{tabular}{|c|c|c|c|c|c|}
\hline $\begin{array}{l}\text { Patient's } \\
\text { number }\end{array}$ & Sex & Age & $\begin{array}{l}\text { Date of onset } \\
\text { of paralysis }\end{array}$ & Diagnosis & $\begin{array}{l}\text { Present method of } \\
\text { urinary bladder drainage }\end{array}$ \\
\hline 1 & M & 57 & 1957 & Traumatic tetraplegia $\mathrm{C} 5 / 6$ & Penile condom drainage \\
\hline 2 & M & 51 & 1989 & Traumatic tetraplegia C-5 & Indwelling urethral catheter drainage \\
\hline 3 & M & 66 & 1982 & Traumatic tetraplegia $\mathrm{C}-5$ & Indwelling urethral catheter drainage \\
\hline 4 & $\mathrm{~F}$ & 69 & 1974 & Multiple sclerosis - flaccid paraplegia & $\begin{array}{l}\text { Indwelling urethral catheter drainage. } \\
\text { Vesical calculus }\end{array}$ \\
\hline 5 & $\mathrm{~F}$ & 71 & 1969 & $\begin{array}{l}\text { Multiple sclerosis - incomplete } \\
\text { tetraplegia }\end{array}$ & $\begin{array}{l}\text { Indwelling urethral catheter drainage } \\
\text { for } 5 \text { years; no catheter for } 3 \\
\text { months }\end{array}$ \\
\hline 6 & M & 24 & 1991 & Traumatic tetraplegia $\mathrm{C}-5$ & $\begin{array}{l}\text { Penile condom drainage. Renal } \\
\text { calculus }\end{array}$ \\
\hline 7 & M & 51 & 1990 & Transverse myelitis Paraplegia T-7 & Indwelling urethral catheter drainage \\
\hline 8 & M & 69 & 1975 & Transverse myelitis Paraplegia T-10 & Penile condom drainage. Bladder stone \\
\hline 9 & M & 45 & 1976 & Traumatic tetraplegia $\mathrm{C}-5$ & Indwelling urethral catheter drainage \\
\hline 10 & M & 51 & 1969 & $\begin{array}{l}\text { Multiple sclerosis Tetraplegia C-4 } \\
\text { incomplete }\end{array}$ & $\begin{array}{l}\text { Indwelling urethral catheter drainage } \\
\text { for the past } 3 \text { years. Vesical calculus }\end{array}$ \\
\hline 11 & M & 66 & 1951 & Traumatic paraplegia $\mathrm{T}-5$ & $\begin{array}{l}\text { Self-catheterisation with penile } \\
\text { condom drainage. Vesical calculus }\end{array}$ \\
\hline 12 & M & 60 & 1991 & Traumatic tetraplegia C-5 incomplete & Suprapubic cystostomy \\
\hline 13 & M & 33 & 1982 & Traumatic paraplegia $\mathrm{T}-6$ & $\begin{array}{l}\text { Indwelling urethral catheter drainage } \\
\text { since } 07 / 10 / 1993\end{array}$ \\
\hline 14 & $\mathrm{~F}$ & 31 & 1983 & Guillain Barre Syndrome Tetraplegia & $\begin{array}{l}\text { Indwelling urethral catheter drainage } \\
\text { since September 1983. Vesical } \\
\text { calculi }\end{array}$ \\
\hline 15 & M & 24 & 1988 & Traumatic paraplegia T-6 & Intermittent self-catheterisation \\
\hline 16 & M & 41 & 1984 & Traumatic tetraplegia $\mathrm{C}-5 / 6$ & Penile condom drainage \\
\hline 17 & M & 62 & 1976 & Traumatic tetraplegia $\mathrm{T}-10$ & $\begin{array}{l}\text { Indwelling urethral catheter drainage } \\
\text { for } 8-9 \text { years. Vesical calculi }\end{array}$ \\
\hline 18 & M & 48 & 1985 & Traumatic tetraplegia C-5 & Penile condom drainage \\
\hline
\end{tabular}


observed urothelial proliferation arrest in spinal cord injury patients may in part be due to abnormalities in the expression of EGF-Receptors in this group of SCI patients. Although neuropathic in origin (by however as yet, an unelucidated mechanism), such altered expression of EGF-Receptors might compromise the topical use of EGF or heparin-binding epidermal growth factor-like growth factor ${ }^{6-8}$ preparations aimed at optimising urothelial proliferation in order to diminish the chances of (pathological) bacterial colonisation on vesical urothelium and biofilm formation.

Further, the malignant potential of the urothelium in the neuropathic bladder following spinal cord injury is well recognised, especially 15 to 20 years after spinal cord trauma. The incidence of vesical malignancy in the spinal cord injury population has been reported to be $2.3 \% .{ }^{9}$ Tumours in these patients are 460 times more common than are urinary bladder tumours in the general population. ${ }^{9}$ The increased occurrence of bladder tumours correlates with the duration of urothelial inflammation, chronic urinary tract infections, vesical stone formation and indwelling catheter drainage of the urinary bladder. EGFR is highly expressed on malignant bladder cancer cells. Apart from conventional therapy for vesical neoplasia, molecular biological approaches are being developed in the laboratory for the possible treatment of neoplasia. The observation that anti-receptor antibodies could revert the malignant phenotype of neu and $c-n e u /$ EGFR transformed cells in vitro and in vivo has been widely reproduced and represents a logical approach to specific anti-tumour therapy which has now been taken to clinical application. ${ }^{10}$

Monoclonal antibodies (MAbs) against four distinct epitopes on the external domain of the EGF receptor were found to inhibit the binding of Transforming Growth Factor and Epidermal Growth Factor to the receptor on tumour cells and these MAbs were able to inhibit the growth in vitro and in vivo of tumour cells that over-express the EGF receptor. ${ }^{11}$ Substances that selectively interfere with Epidermal Growth Factor Receptor tyrosine kinase have potential for the therapy of bladder cancer. ${ }^{12}$ Potent tyrosine kinase inhibitors of the EGFR kinase arrest the growth of cells that over-express EGFR and inhibit tumours that over-express EGFR. ${ }^{13}$ Systemic administration of keratinocyte growth factor, also known as FGF-7, which belongs to the fibroblast growth factor family of cytokines in a dose of $5 \mathrm{mg} / \mathrm{kg}$ resulted in rapid and striking proliferation of vesical urothelium in rats and rhesus monkeys. ${ }^{14}$ Such a fundamental approach to modulation of urothelial proliferation is being considered for SCI patients, as drugs directed against the fundamental molecular mechanisms responsible for a specific pathology are nearly always more effective and less toxic than agents that merely treat the consequences of a pathological process. ${ }^{15}$ As more information on the factual distribution of EGFR in the urothelium of SCI patients was required before any treatment strategy could be considered, we investigated the EGFR expression and localization in vesical urothelium of consecutive unselected spinal cord injury patients.

\section{Patients and methods}

\section{Study population}

Eighteen adult spinal cord injury patients who were otherwise scheduled for a therapeutic procedure such as division of the external urethral sphincter and transurethral resection of the bladder neck $(n=5)$, electrohydraulic lithotripsy of vesical stone(s) $(n=4)$, suprapubic cystolithotomy $(n=2)$, suprapubic cystostomy $(n=1)$, JJ stent insertion $(n=1)$, removal of $\mathrm{JJ}$ stent $(n=1), \quad$ ureterorenoscopy $(n=1)$, attempted insertion of ureteric stent $(n=1)$ or, diagnostic cystoscopy for evaluation of haematuria $(n=2)$ were the subjects of this study. The details of the proposed investigation (bladder biopsy) were discussed with the patient and his/her carer(s) and written informed consent was obtained from all of the patients. A cold-cup biopsy was taken under vision from the normal-looking bladder mucosa from the trigone of the urinary bladder. Any bleeding point was then fulgurated with diathermy electrode. Performance of bladder biospy did not result in any additional morbidity in these eighteen patients.

\section{Biopsy procedure, tissue sampling}

Cold-cup biopsies were either fixed in $0.1 \mathrm{M}$, phosphate buffered, $4 \%$ formaldehyde, $\mathrm{pH} 7.4$ for $6-24 \mathrm{~h}$ for routine histopathological analysis or snap frozen in liquid nitrogen and subsequently stored at $-80 \mathrm{C}$ for immunohistochemical analysis of EGFR-protein distribution.

\section{EGFR analysis, immunocytochemistry}

Five micron frozen sections were cut at $-24^{\circ} \mathrm{C}$ by Cryotome, mounted on coated slides and used for analysis with a commercially available, affinity purified monoclonal mouse anti-human epidermal growth factor receptor antibody (DAKO-EGF-Receptor, EGFR1, code no. M 886, Lot 101). DAKO EGFReceptor, EGFR1 (DAKO, A/S, Produktionsvej 42, DK-2600 Glostrup, Denmark) reacts with the external domain of the epidermal growth factor receptor (MW $170 \mathrm{kD})$. Demonstration of binding used alkaline phosphatase and alpha-naphthol chromagen. The intensity of immunostaining was graded semiquantitatively for each patient on a six point scale ranging from negative, questionable $(+/-)$, mildly to very strongly positive on the remaining four points of the grading system $(+$ to ++++$)$. 
Table 2 Histopathological and immunohistochemical findings of epidermal growth factor receptor expression and distribution in the urinary bladder trigone biopsy of the 18 SCI patients

\begin{tabular}{|c|c|c|c|c|c|}
\hline $\begin{array}{l}\text { Laboratory } \\
\text { number, } \\
\text { Patient's } \\
\text { Number, and } \\
\text { Site of Biopsy }\end{array}$ & Histopathology & $\begin{array}{l}\text { Strength of } \\
\text { EGFR-p } \\
\text { expression }\end{array}$ & $\begin{array}{l}\text { Location } \\
\text { in layers }\end{array}$ & $\begin{array}{l}\text { Sub-basement } \\
\text { membrane } \\
\text { expression }\end{array}$ & $\begin{array}{l}\text { Type of } \\
\text { expression }\end{array}$ \\
\hline $\begin{array}{l}\mathrm{H} 95 / 1405 \\
1, \text { Trigone }\end{array}$ & $\begin{array}{l}\text { Urothelial layer thickness of approximately eight cells. There is moderate, active } \\
\text { inflammatory infiltrate, occasionally with polymorphonuclear cells which show } \\
\text { active invasion into the superficial urothelium, Follicular cystitis } \\
\text { Partial intestinal metaplasia } \\
\text { Focal, early squamous metaplasia }\end{array}$ & ++ & $\begin{array}{l}0-7 \text {, continuous } \\
\text { from basal layer }\end{array}$ & + & $\begin{array}{l}\text { Cell membrane } \\
\text { and cytoplasmic }\end{array}$ \\
\hline $\begin{array}{l}\text { H94/3414 } \\
2 \text {, Trigone }\end{array}$ & $\begin{array}{l}\text { There is limited invasion of the urothelium by lymphocytes. The superficial } \\
\text { submucosa shows a diffusely distributed lymphocytic infiltrate and occasional } \\
\text { mature plasma cells }\end{array}$ & ++ & $\begin{array}{l}0-3, \text { continuous from } \\
\text { basal layer }\end{array}$ & \pm & Cytoplasmic \\
\hline $\begin{array}{l}\mathrm{H} 95 / 1132 \\
3 \text {, Trigone }\end{array}$ & Follicular cystitis & + & $\begin{array}{l}0-4 \text {, continuous from } \\
\text { basal layer }\end{array}$ & 0 & Cytoplasmic \\
\hline $\begin{array}{l}\mathrm{H} 95 / 0266 \\
4, \text { Trigone }\end{array}$ & Areas of denuding cystitis & ++ & $\begin{array}{l}0-5 \text {, continuous from } \\
\text { basal layer }\end{array}$ & 0 & Cytoplasmic \\
\hline $\begin{array}{l}\text { H } 95 / 0268 \\
5 \text {, Trigone }\end{array}$ & $\begin{array}{l}\text { Complete squamous metaplasia. There is no gross atypia and a limited } \\
\text { inflammatory change }\end{array}$ & ++ & $\begin{array}{l}0-8, \text { continuous from } \\
\text { basal layer }\end{array}$ & \pm & Cell membrane \\
\hline $\begin{array}{l}\text { H95/0489 } \\
6 \text {, Trigone }\end{array}$ & $\begin{array}{l}\text { Limited oedema and small vessel proliferation with completely absent } \\
\text { inflammatory infiltrate }\end{array}$ & + & $\begin{array}{l}0-9, \text { continuous from } \\
\text { basal layer }\end{array}$ & 0 & Cytoplasmic \\
\hline $\begin{array}{l}\text { H } 94 / 2525 \\
7, \text { Trigone }\end{array}$ & $\begin{array}{l}\text { There is limited inflammatory infiltrate with a clear perivascular concentration } \\
\text { consisting mainly of lymphocytes and plasma cells with occasional accumulation } \\
\text { of polymorphonuclear cells }\end{array}$ & + & 2-top, discontinous & 0 & Cytoplasmic \\
\hline $\begin{array}{l}\text { H95/0487 } \\
8 \text {, Trigone }\end{array}$ & Extensive early intestinal metaplasia & \pm & $\begin{array}{l}0-5 \text {, continuous from } \\
\text { basal layer }\end{array}$ & 0 & Cytoplasmic \\
\hline $\begin{array}{l}\text { H94/3416 } \\
9, \text { Trigone }\end{array}$ & $\begin{array}{l}\text { There is a dense inflammatory infiltrate with granulation tissue development in } \\
\text { the submucosa. In addition to lymphocytes, plasma cells, and iron laden } \\
\text { macrophages, polymorphonuclear cells are seen which often invade the } \\
\text { superficial lining epithelium }\end{array}$ & + & $\begin{array}{l}2-3, \text { discontinuous } \\
\text { from basal layer }\end{array}$ & + & Cytoplasmic \\
\hline $\begin{array}{l}\text { H95/0771 } \\
10 \text {, Trigone }\end{array}$ & Active, chronic follicular cystitis & ++ & $\begin{array}{l}0-2 \text { continuous from } \\
\text { basal layer }\end{array}$ & 0 & Cytoplasmic \\
\hline $\begin{array}{l}\text { H95/1233 } \\
11 \text {, Trigone }\end{array}$ & $\begin{array}{l}\text { There is no evident inflammation and no inflammatory infiltrate in the deeper } \\
\text { layers }\end{array}$ & ++ & $\begin{array}{l}1-3, \text { continuous from } \\
\text { basal layer }\end{array}$ & \pm & Cytoplasmic \\
\hline $\begin{array}{l}\text { H95/1274 } \\
12 \text {, Trigone }\end{array}$ & $\begin{array}{l}\text { There is a diffuse inflammatory infiltrate of limited extent consisting mainly of } \\
\text { lymphocytes which do not show evident lymphocytic migration into the } \\
\text { overlying urothelium }\end{array}$ & \pm & $\begin{array}{l}0-1 \text {, continuous from } \\
\text { basal layer }\end{array}$ & \pm & $\begin{array}{l}\text { Cytoplasmic } \\
\text { and Cell } \\
\text { membrane }\end{array}$ \\
\hline $\begin{array}{l}\text { H95/1407 } \\
13 \text {, Trigone }\end{array}$ & $\begin{array}{l}\text { The oedematous submucosa shows a sparse infiltrate of lymphocytes and no } \\
\text { evident superficial invasion }\end{array}$ & + & $\begin{array}{l}0-2, \text { continuous from } \\
\text { basal layer }\end{array}$ & \pm & Cytoplasmic \\
\hline $\begin{array}{l}\text { H95/1276 } \\
14 \text {, Trigone }\end{array}$ & Complete squamous metaplasia & ++ & $\begin{array}{l}0-3 \text {, continuous from } \\
\text { basal layer in urothe- } \\
\text { lium and } 0-7 \text { in squa- } \\
\text { mous metaplasia }\end{array}$ & \pm & $\begin{array}{l}\text { Cytoplasmic in } \\
\text { urothelium and } \\
\text { Cell membrane } \\
\text { in squamous } \\
\text { metaplasia }\end{array}$ \\
\hline
\end{tabular}


Analysis

The slides were read twice, blind, in randomised order, and patients biopsied. Five randomly chosen sites per biopsy were assessed. Histopathology of the bladder mucosal biopsy from the trigone, and immunohistochemical observations on EGFR-p immunostaining viz (1) intensity of immunostaining as graded semiquantitatively on a six point scale, (2) location of EGFR-p positivity in urothelial cell layers, (3) sub-basement membrane expression of EGFR-p, and (4) type of expression of EGFR-p (whether cytoplasmic or, cell membrane or, both cytoplasmic and cell membrane positive immunostaining), were recorded for each patient.

\section{Results}

Of the 18 SCI patients in whom bladder biopsy was taken, nine were on indwelling urethral catheter drainage; five were on penile condom drainage; two were performing intermittent catheterisation; one was on suprapubic drainage and one woman was using pads with reflex voiding (Table 1). Histopathology of the bladder biospy revealed denuding cystitis in one; follicular cystitis in four; active inflammatory infiltrate in three (in a tetraplegic patient on indwelling catheter drainage, there was dense inflammatory infiltrate with granulation tissue development in the submucosa); lymphocytic infiltrate in three; squamous metaplasia in six; and intestinal metaplasia in three biopsy specimens (Table 2). A linear localization of epidermal growth factor receptor along the cell membrane of the urothelium was observed in three cases (Figure 1). Cytoplasmic immunostaining of epidermal growth factor receptor was noted in 13 cases (Figure 2). Both cytoplasmic and cell membrane immunostaining were seen in two cases (Figure 3). In one patient, small aggregates of cells at mid-epithelial height showed strong cytoplasmic positivity of EGFR-p (stored?) separated from the basement membrane by $2-3$ layers of negative urothelial cells (Figure 4). The three cases with membrane immunostaining showed strong expression of EGFR $\left(2^{+}, 2-3^{+}\right.$, and $4^{+}$respectively). The intensity of EGFR expression varied in cases of cytoplasmic immunostaining: $2^{+}$intensity in six cases; $1-2^{+}$intensity in one; $1^{+}$staining in five cases; and $+/-$ immunostaining in one patient. Presence of EGFR-p antigen in sub-basement membrane location, presumably on transmembranous cell protrusions, was not unequivocally recognised in patients with cytoplasmic expression, and only considered to be present in those cases with cell membrane localisation.

The three specimens showing cell membrane location of EGFR-p were from patients who did not have an indwelling urethral catheter (a paraplegic man practising intermittent self-catheterisation, a tetraplegic patient on penile condom drainage, and a tetraplegic woman with reflex voiding), and histopathology of bladder biopsy revealed a uniform picture of a limited or very little inflammatory 
infiltrate with especially no evidence of invasion of the urothelium by inflammatory cells. In contrast, the biopsies from all the nine patients, who were on indwelling urethral catheter drainage, showed only

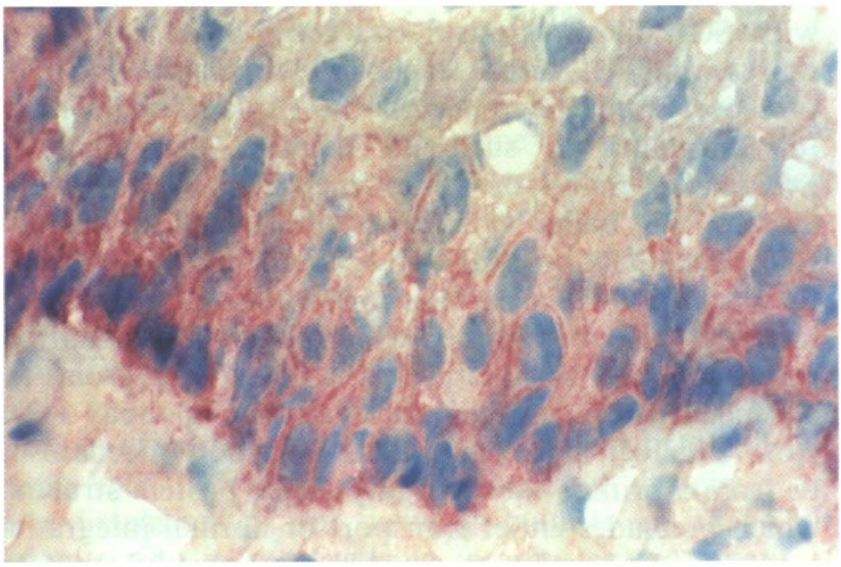

Figure 1 Microphotograph of 5 micron section of urinary bladder trigone biopsy in a tetraplegic patient stained for the presence of EGRF-p by routine alkaline phosphatase immunocytochemistry. Note presence of antigen clearly distributed along intracellular boundaries, i.e. at the cell membrane. Microscopical magnification $200 \times$

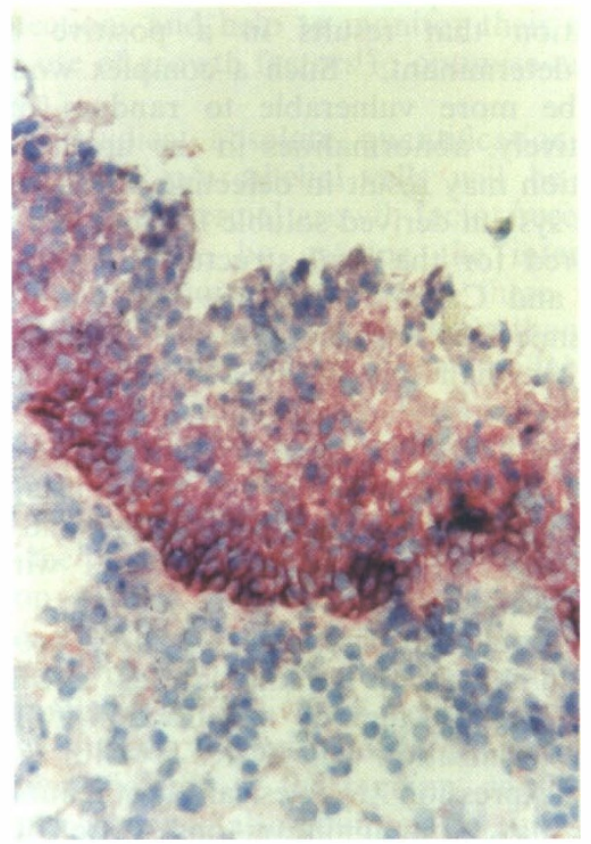

Figure 2 Microphotograph of 5 micron section of urinary bladder trigone biopsy in a tetraplegic patient stained for the presence of EGFR-p by routine alkaline phosphatase immunocytochemistry. Note presence of antigen in this patient is clearly distributed diffusely over the cytoplasm of the lower half of the urothelium. Microscopical magnification $200 \times$ cytoplasmic location of EGFR-p. Histopathology of bladder biopsy in this group of patients showed a spectrum of changes varying from 'completely absent inflammatory infiltrate', to 'dense inflammatory infiltrate with granulation tissue development and invasion of the superficial lining epithelium by polymorphonuclear cells'. Six patients had vesical calculi and

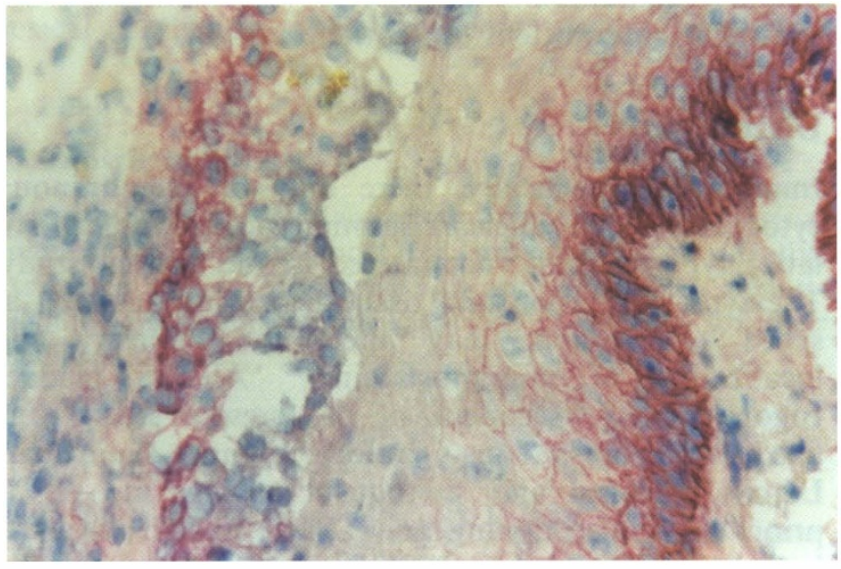

Figure 3 Microphotograph of 5 micron section of urinary bladder trigone biopsy in a tetraplegic patient stained for the presence of EGFR-p by routine alkaline phosphatase immunocytochemistry. Note the presence in this single patient/biopsy site of two, clearly distinct patterns of antigen expression/receptor protein localisation. Note cytoplasmic presence of receptor protein in urothelium lining on left (basal $2-3$ cell layers) and the well developed cell boundary/ cell membrane distribution of the antigen on the right (lower half/two-third of urothelium). Microscopical magnification $200 \times$

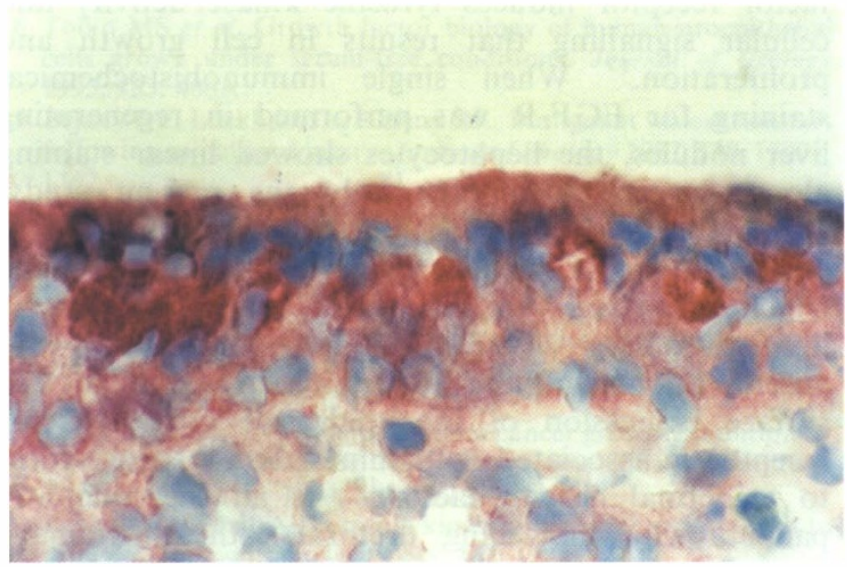

Figure 4 Microphotograph of alternative pattern of EGFR$\mathrm{p}$ distribution found in a SCI patient. Note the presence of a small group of cells with strong cytoplasmic presence of (stored?) EGFR-protein separated from the basement membrane by $2-3$ layers of EGFR-p negative urothelial cells. (See text). Microscopical magnification $1000 \times$ 
cytoplasmic immunostaining of EGFR-p was observed in the vesical urothelium of all the six cases, albeit cell membrane localisation of EGFR-p was seen in the squamous metaplastic region of the biopsy in one patient (BC). The histopathology of trigone biopsy in these patients with vesical calculus showed denuding cystitis in one case, squamous metaplasia in two, intestinal metaplasia in one, follicular cystitis in one, and no inflammatory infiltrate in a patient who was practising intermittent self-catheterisation.

\section{Discussion}

Immunohistochemically, there may be membranous, cytoplasmic, or nuclear immunolocalization. ${ }^{16}$ The latter type was not encountered in the present study. The type of fixation and tissue processing, as well as speed of fixation, may affect the intensity and localization of immunostaining. ${ }^{16}$ All 18 bladder trigone biopsy specimens of the present study were fixed and processed in a uniform manner (immediate Liquid Nitrogen and subsequent storage at $-80^{\circ} \mathrm{C}$ prior to cryo-sectioning at $-24^{\circ} \mathrm{C}$ ) thus ruling out both variability and insufficiency due to deficiencies/ differences in fixation or processing techniques. Thus the absence of nuclear location of EGFR-protein antigen presence, at least over the detection levels of the technique used, in these human tissues is to be accepted.

The normal pattern of (detectable) expression of EGFR-p is on the cell membrane. In this study, this was found as the sole mode of expression in three patients. In two patients cell membrane presence was combined with cytoplasmic expression: in one patient in side-by-side; in one patient by the presence of both distributions within single cells. Stimulation of the normally located, i.e. functional epidermal growth factor receptor induces tyrosine kinase activity and cellular signalling that results in cell growth and proliferation. ${ }^{17}$ When single immunohistochemical staining for EGF-R was performed in regenerating liver nodules, the hepatocytes showed linear staining along the cell membrane. ${ }^{18}$ In the present study, immunohistochemical localization of EGFR-p was performed on 18 bladder mucosal biopsies from the trigone and in 13 of them, only cytoplasmic immunostaining of EGFR-p was observed with absent cell membrane expression. Decline in cell surface expression of the epidermal growth factor receptor is associated with diminished responsiveness to epidermal growth factor. ${ }^{19}$ As all the nine SCI patients with indwelling urethral catheter drainage showed only cytoplasmic location of EGFR-p, the potential for intravesical administration of EGFR as a treatment modality may be limited.

Thirteen patients showed unequivocal cytoplasmic presence of EGFR-p antigen. Decrease in cytoplasmic staining of EGFR may reflect either a defect of internalization from the plasma membrane, decreased synthesis, increased degradation and/or distribution to another cell compartment (nucleus). Indeed, there is circumstantial evidence that all three could be involved in the phenomena of decreased cytoplasmic EGF receptor content. ${ }^{20}$ In contrast, we observed cytoplasmic localisation of EGFR-p in the absence of cell membrane immunostaining in 13 of the 18 patients with SCI. In these cases this may be interpreted as representing a raised level of cytoplasmic EGFR-p presence. With reference to the explanations offered for a reduction, such an increase may then be explained by any or all of the same, but reversed, factors. As under normal circumstances a negative feed back effect on EGFR-p synthesis may be expected to result from successful incorporation of the protein into the cell membrane, excess cytoplasmic antigen presence may be interpreted as resulting from the absence of negative feed back effects. This may result from a defect in post-synthesis transport mechanisms or from a primary abnormality of the protein structure which precludes either transport or normal integration into the cell membrane. Should the latter be the case, failure of EGFR to localize the cell membrane may mean the absence of EGFR sequences necessary for appropriate cell membrane localization. It is known that human EGFRs truncated at Arg-651 were localized predominantly at the apical surface of filter-grown cells, whereas receptors truncated at Leu-723 were located predominantly basolateral, thus suggesting that the gene controlling the synthesis of the finalised receptors also contains complex structural information that results in a positive basolateral sorting determinant. ${ }^{21}$ Such a complex would theoretically be more vulnerable to random disruptions. Alternatively, abnormalities in the urothelial mucosa innervation may result in defective normal gradient of nervous system derived soluble factors. If this gradient is required for the final structuring as described by Hobert and Carlin, ${ }^{21}$ then the resultant increase of cytoplasmic EGFR-p may represent incomplete synthesis rather than a primary defective product which cannot be integrated precluding negative feed back restriction of the (first steps of the) synthesis process. Thus a detailed study of the relationship between abnormalities of EGFR-p distribution and urothelial nerve fibre abnormalities in patients with SCI is warranted and required.

Cytoplasmic localization of c-erbB-2 product p185 in human mammary carcinoma was associated with low proliferating tumour cell fraction. ${ }^{22}$ Thus cytoplasmic localization of EGRF-p with absent cell surface expression in vesical urothelium of SCI patients may be a significant observation in the light of the fact that vesical urothelial proliferation arrest has been reported in SCI patients. ${ }^{5}$ Further, there is evidence suggesting colocalization and correlations in the expression of EGFR and the cell-cell adhesion molecule E-cadherin. Immunolocalization of E-cadherin was enhanced in cell lines expressing functional or hyperfunctional EGFR, compared to cell lines expressing non-functioning mutant EGFR, or no 
EGFR at all. ${ }^{23}$ Thus alterations in the expression of EGFR in SCI patients, as observed in the present study, may in turn result in changes in E-cadherin expression (as EGFR activation may regulate or enhance E-cadherin expression) and may either lead to increased cell-cell adhesion or disruption of cell-cell adhesion. SCI patients with reduced expression of EGFR or those expressing non-functional EGFR (non-functioning mutant EGFR, or no functional EGFR per se), may become prone to develop cystitis partly due to changes in E-cadherin expression since E-cadherin may play an important role in bacterial adhesion on the urothelial cells and thus may contribute to abnormal bacterial colonisation of neuropathic bladder. Indeed, some SCI patients suffer from frequent episodes of cystitis in the absence of any other apparent predisposing factor(s) for the development of urinary tract infection, e.g. blocked catheter in those with indwelling urethral catheter drainage, or over-distension of the urinary bladder in the SCI patients who were practising intermittent catheterisation, or retention of large amounts of urine in those with penile condom drainage, vesical stone(s), etc. Immunohistochemical studies of (1) EGFR expression on vesical urothelium and (2) proliferating cell nuclear antigen and $\mathrm{Ki}-67$ in these SCI patients who develop recurrent episodes of cystitis may provide insight to the urothelial proliferation disorders in the neuropathic bladder which probably contribute to their susceptibility for development of frequent episodes of urinary infections and help to monitor their response to possible use of growth factors to optimise urothelial proliferation.

In future studies, absolute quantification of the amount of EGFR-p/urothelial cells will be of use. Quantification of epidermal growth factor receptors in this study was made by grading the intensity of immunostaining semiquantitatively as there is more antigen present in cells that stain strongly than in cells that stain weakly. ${ }^{16}$ However, understandably, this method gives only a limited and approximate assessment of the number of EGF receptors on single cells. Confocal laser scanning microscopy is a powerful tool for detecting EGFR on single cells. Using EGFbiotin as the ligand to bind the EGF receptor in combination with a fluorescent secondary antibody, Good and associates ${ }^{24}$ demonstrated that confocal laser scanning microscopy is able to quantify EGF receptor numbers on individual cells, with a lower limit below 10000 receptors/cell. In addition to allowing quantification of the binding, confocal laser scanning microscopy is also equipped to study growth factor receptor localization, either by applying threedimensional visualization through stereo images, or by making optical sections. Thus a longitudinal study of the localization and quantification of epidermal growth factor receptors on single urothelial cells by confocal laser scanning microscopy in SCI patients in a sequential manner, preferably annually after spinal cord trauma, and correlation of these findings with the clinical observations of urinary tract infections as well as histological changes of urothelial inflammation of urinary tract infections as well as histological changes of urothelial inflammation, atrophy, and metaplasia/ dysplasia or neoplasia, should it occur, will contribute to better understanding of the altered urinary bladder physiology in SCI patients and in turn, provide the scientific rationale for innovative treatment strategies for the inappropriate expression of EGFR in the vesical urothelium of SCI patients.

\section{Acknowledgements}

Our gratitude to Ms Jacqueline Steven, Regional Spinal Injuries Centre, Southport for providing administrative assistance and to Mrs F McGill and E Hughes, Department of Fetal and Infant Pathology, Liverpool for their technical support.

\section{References}

1 See WA. Commentary on growth factors: The bread-and-butter cytokines of urology. Journal of Urology 1994; 152: 1942.

2 Carpenter G, Cohen S. Epidermal growth factor. Minireview. The Journal of Biological Chemistry 1990; 265: 7709-7712.

3 Messing EM. Clinical implications of the expression of epidermal growth factor receptors in human transitional cell carcinoma. Cancer Research 1990; 50: 2530 - 2537.

4 Messing EM, Hanson P, Ulrich P, Erturk E. Epidermal growth factor - Interactions with normal and malignant urothelium: in vivo and in situ studies. Journal of Urology 1987: 138: 1329-1335.

5 van Velzen et al. Vesical urothelial proliferation in spinal cord injury patients: an immunohistochemical study of PCNA and MIB-1 labelling. Paraplegia 1995; 33: $523-529$.

6 Duel BP, Freeman M, Atala A. Expression of heparin-binding epidermal growth factor-like factor mRNA in a new model of urothelial injury. Journal of Urology 1995; 153: 265A.

7 Freeman MR et al. Human urothelial cells secrete and are regulated by heparin-binding epidermal growth factor-like factor. Journal of Urology 1995; 153: 307A.

8 Tobin MS et al. Growth factor biology of human uroepithelial cells grown under serum-free conditions. Journal of Urology 1995; 153: 406A

9 Bejany DE, Lockhart JL, Rhamy RK. Malignant vesical tumours following spinal cord injury. Journal of Urology 1987; 138: 1390 1392.

10 Dougall WC et al. The neu-oncogene: signal transduction pathways, transformation mechanisms and evolving therapies. Oncogene 1994; 9: 2109-2123.

11 Modjtahedi $\mathrm{H}$ et al. Antitumour activity of combination of antibodies directed against different epitopes on the extracellular domain of the human EGF receptor. Cell Biophys 1993; 22: 129 146

12 Dong Z, Fidler I, Dinney C. Bladder cancer growth inhibition by epidermal growth factor receptor tyrosine kinase inhibitors. Journal of Urology 1994; 151: 392A.

13 Levitzki A, Gazit A. Tyrosine kinase inhibition: an approach to drug development. Science 1995; 267: 1782 -- 1788.

$14 \mathrm{Yi}$ ES et al. Keratinocyte growth factor causes proliferation of urothelium in vivo. Journal of Urology 1995; 154: 1566-1570.

15 Gibbs JB, Oliff A. Pharmaceutical research in molecular oncology. Cell 1994; 79: 193 - 198.

16 Grizzle WE, Myers RB, Arnold MM, Srivastava S. Evaluation of biomarkers in breast and prostate cancer. Journal of Cellular Biochemistry, Supplement 1994; 19: 259-266.

17 Carpenter G. Receptors for epidermal growth factor and other polypeptide mitogens. Ann Rev Biochem 1987; 56: 881 -914. 
18 Yamaguchi K, Carr BI, Nalesnik MA. Concomitant and isolated expression of TGF-alpha and EGF-R in human hepatoma cells supports the hypothesis of autocrine, paracrine, and endocrine growth of human hepatoma. J Surg Oncol 1995; 58: 240-245.

19 Suarez-Quian CA, Byers SW. Redistribution of epidermal growth factor receptor as a function of cell density, cell-cell adhesion and calcium in human (A-431) cells. Tissue-Cell 1993; 25: $1-17$.

20 Oguey D, Reichen J, Marti U. Differential effect of micronodular and biliary cirrhosis on epidermal growth factor receptor expression in the rat. Journal of Hepatology 1994; 21: 997-1005.

21 Hobert M, Carlin C. Cytoplasmic juxtamembrane domain of the human EGF receptor is required for basolateral localization in MDCK cells. J Cell Physiol 1995; 162: 434-446.
22 Zschiesche W, Schonborn I, Minguillon C, Spitzer E. Significance of immunohistochemical c-erbB-2 product localization pattern for prognosis of primary human breast cancer. CancerLett 1994; 81: 89-94.

23 Sorscher SM, Green MR, Feramisco JR. Enhanced E-cadherin expression in epidermal growth factor receptor expressing cells. Biochemical and Biophysical Research Communications 1995; 206: $518-524$.

24 Good MJ et al. Localization and quantification of epidermal growth factor receptors on single cells by confocal laser scanning microscopy. The Journal of Histochemistry and Cytochemistry 1992; 40: $1353-1361$. 